\title{
All-black front surfaces for building-integrated photovoltaics
}

\author{
landolo, Beniamino; Mizushima, lo; Davidsen, Rasmus S.; Tang, Peter T.; Hansen, Ole
}

Published in:

Japanese Journal of Applied Physics

Link to article, DOI:

10.7567/JJAP.57.08RH01

Publication date:

2018

Document Version

Peer reviewed version

Link back to DTU Orbit

Citation (APA):

landolo, B., Mizushima, I., Davidsen, R. S., Tang, P. T., \& Hansen, O. (2018). All-black front surfaces for building-integrated photovoltaics. Japanese Journal of Applied Physics, 57(8), [08RH01].

https://doi.org/10.7567/JJAP.57.08RH01

\section{General rights}

Copyright and moral rights for the publications made accessible in the public portal are retained by the authors and/or other copyright owners and it is a condition of accessing publications that users recognise and abide by the legal requirements associated with these rights.

- Users may download and print one copy of any publication from the public portal for the purpose of private study or research.

- You may not further distribute the material or use it for any profit-making activity or commercial gain

- You may freely distribute the URL identifying the publication in the public portal

If you believe that this document breaches copyright please contact us providing details, and we will remove access to the work immediately and investigate your claim 


\section{All-black front surfaces for building-integrated photovoltaics}

Beniamino Iandolo ${ }^{1, *}$, Io Mizushima ${ }^{2}$, Rasmus S. Davidsen ${ }^{1}$, Peter T. Tang ${ }^{2}$ and Ole Hansen ${ }^{1}$ ${ }^{1}$ DTU Nanotech, Technical University of Denmark, Kgs. Lyngby, DK-2800, Denmark ${ }^{2} I P U$, Kgs. Lyngby, DK-2800, Denmark

*E-mail: benian@nanotech.dtu.dk

Widespread implementation of building integrating photovoltaics requires aesthetically pleasant panels. Black surfaces are often visually appealing and, if based on a black photoabsorber, may lead to increased panel efficiency. Here, we demonstrate a combination of black silicon and black ribbons (or bus-bars), both fabricated with methods that are compatible with production lines of screen-printed, front contacted solar panels. Maskless, non-cryogenic reactive ion etch of silicon and subsequent coating with aluminum oxide for passivation purposes results in average reflectance of less than $1 \%$ in the UV-vis part of the solar spectrum, and in minority carrier lifetimes similar to those obtained on polished reference samples thanks to minimized surface damage, as confirmed by transmission electron microscopy. Inorganic blackening of bus-bars by a combination of electroplating and chemical etching results in reflectance values lower than 3.5\% in the UV-vis, with no modifications to standard stringing equipment required. 


\section{Introduction}

Developing aesthetically pleasant solar panels without excessive losses in power conversion efficiency is paramount to the broad diffusion of building-integrated photovoltaics ${ }^{1-3)}$. A possible route, actually leading to increased efficiency, consists in replacing the standard wet textured silicon (obtained by alkaline and acidic texturing for mono- and multi-crystalline $\mathrm{Si}$, respectively) with black silicon, which shows superior light trapping properties ${ }^{4)}$.

The expression black silicon (hereinafter b-Si), encompasses several types of nanostructured $\mathrm{Si}$ that exhibit strongly suppressed optical reflection at the $\mathrm{Si}$-air interface ${ }^{5)}$. A strong candidate for fabrication of $b-\mathrm{Si}$ is maskless, reactive ion etch (RIE) ${ }^{6,7)}$. RIE can be used with success to texture any type of Si surface ${ }^{8)}$, and if performed at non-cryogenic temperatures ${ }^{9)}$ is readily compatible with existing production lines without dramatic increase in fabrication costs ${ }^{10)}$. Furthermore, it does not suffer from metallic contamination as is the case for b-Si fabricated by metal assisted chemical etching (MACE), the other method of choice to obtain $\mathrm{b}-\mathrm{Si}^{11-13)}$. Finally, RIE offers a large parameter space for process tuning resulting in both ultra-low optical reflection and minimized surface charge carrier recombination ${ }^{14)}$. Cell efficiencies of $22.1 \%$ and $21.9 \%$ have recently been reported for interdigitated back contact float-zone (FZ) Si and multi-crystalline Si respectively ${ }^{15,16)}$, with cryogenic RIE as front surface texturing. Also, cells with b-Si texturing are less affected by variation in incidence angle of light as compared to conventional textured cells ${ }^{17)}$, which is particularly relevant for building-integrated applications. Here, we have fabricated black Si by non-cryogenic RIE reaching the following targets: (i) average reflectance lower than $1 \%$ throughout the UV-vis part of the solar spectrum; and (ii) minority carrier lifetime values approaching those measured on polished Si wafers, as result of an optimized RIE process that leads to minimal surface damage.

Replacing wet textured $\mathrm{Si}$ with $\mathrm{b}-\mathrm{Si}$ is clearly not the only modification required to improve the aesthetics of front-contacted panels, as sketched in Fig. 1. The current collecting strings, or bus-bars, display high reflectance in the visible due to their metallic nature (typically consisting of SnPbAg alloys). It follows that b-Si must be matched with bus-bars of similar appearance. Some bus-bars with dark appearance are commercialized. For example, Bruker-Spaleck produces solar ribbons with organic paint coating ${ }^{18)}$, while dark appearance ribbons with V-shaped structure invented by E. M. Sachs ${ }^{19)}$ are produced by Ulbrich $^{20)}$. Otherwise, few inorganic black bus-bars have been seen so far. In order to address this deficiency, we have developed a process for blackening bus-bars by combining metal coating by electroplating with chemical etching of the metal surface. The process is 
compatible with large-volume industrial production and the coating is completely inorganic, thus expected to show excellent resistance to degradation by UV-light. Furthermore, the busbars are compatible with standard stringing equipment. Finally, they show reflectance of $4 \%$ or lower in the UV-vis range, thus matching the very low reflectance obtained by RIEtextured $\mathrm{Si}$ and making such a combination a very promising all-black front surface for standard processed solar cells.

\section{Experimental methods}

\subsection{Fabrication of black silicon and lifetime samples.}

$100 \mathrm{~mm}$ diameter Czochralski (CZ) mono-crystalline (100) p-type doped Si wafers with thickness $350 \pm 25 \mu \mathrm{m}$ were textured using maskless RIE at $-20{ }^{\circ} \mathrm{C}$ in a Pegasus system (STS) using the following parameters: gas flow ratio $\mathrm{O}_{2}: \mathrm{SF}_{6} \approx 10: 7$, chamber pressure of $4.5 \mathrm{~Pa}$, coil power of $3000 \mathrm{~W}$ and platen power of $10 \mathrm{~W}$ or $60 \mathrm{~W}$ (both operating at 13.56 $\mathrm{MHz}$ radio-frequency), etching time $14 \mathrm{~min}$. The wafers were then RCA cleaned, without the final oxide strip in hydrofluoric acid in order to leave on the surface the chemical oxide grown during RCA2. Subsequently, the wafers were coated with 380 cycles of $\mathrm{Al}_{2} \mathrm{O}_{3}$ synthesized at $200{ }^{\circ} \mathrm{C}$ using trimethyl-aluminum (TMA) and $\mathrm{H}_{2} \mathrm{O}$ as precursors for $\mathrm{Al}$ and $\mathrm{O}$, respectively, in an atomic layer deposition (ALD) process. These passivation layers were activated by post-deposition annealing for $10 \mathrm{~min}$ at $400{ }^{\circ} \mathrm{C}$ in a $\mathrm{N}_{2}$ atmosphere using a Tempress furnace. For reference purposes, double-side polished wafers were also passivated and annealed.

\subsection{Fabrication of black bus bars.}

Both of electroplating and chemical etching of bus-bars were performed in a $1 \mathrm{~L}$ beaker at room temperature. The solutions were agitated with a magnetic stirrer. The bus-bars were degreased cathodically in an alkaline solution and pickled in a commercial acidic solution prior to the blackening process. After electroplating the bus-bars were rinsed with DI water, and immediately immersed in the chemical etching solution. Finally the bus-bars were with blow-dried using an air gun.

\subsection{Characterization}

The thickness of the $\mathrm{Al}_{2} \mathrm{O}_{3}$ layer was measured using ellipsometry (VASE J. A. Woollam Co.). Optical spectroscopy was performed in a UV spectrophotometer (UV-2600, Shimadzu Co.). Scanning electron microscopy (SEM) images were taken using a Carl Zeiss Supra 40VP 
microscope at an acceleration voltage of $5 \mathrm{kV}$. Transmission electron microscope (TEM) images were acquired using a Titan 80-300 TEM microscope (FEI) at an accelerating voltage of $300 \mathrm{kV}$. Single nanostructures were isolated by pressing a Cu TEM grid with holey carbon on top of textured wafers. Effective lifetime measurements were performed using the microwave detected photoconductivity (MDP) method in transient and injection dependent single point mode, using a MDP mapper from Freiberg Instruments. In order to determine whether the blackened bus-bars were damaged upon stringing, cross-sections of bus-bars before and after soldering to a Si wafer were inspected using an optical microscope. For the observation a bus-bar and a piece of Si wafer with soldered bus-bar were mounted on epoxy resin separately, and the cross-sections were polished mechanically.

\section{Results and discussion}

\subsection{Optical reflectance.}

The first key metric to assess our procedures for suppressing reflection of light by Si and by the black bus-bars, clearly, is optical spectroscopy. Figure 2 summarizes the results of measurements of reflectance $(R)$ in the wavelength range from 300 to $800 \mathrm{~nm}$ for b-Si and blackened bus-bars and compared to the reflectance of polished Si surfaces and of standard bus-bars obtained by soldering. After RIE texturing, the b-Si sample shows reflectance between 3 and $6 \%$ in the UV-A (300-400 nm wavelength), and lower than 3\% throughout the visible spectrum. This is already lower reflectance than that of Si surfaces obtained by wet texturing ${ }^{21,22)}$. Although RIE is capable of producing Si surfaces with yet lower reflectance ${ }^{5)}$, the reflectance obtained here is already low enough to relax requirements on thickness and composition of any anti reflective coating (ARC). This gives us an additional, useful handle to play with in terms of which material to choose for surface passivation (see also the following Subsection). We chose $\mathrm{Al}_{2} \mathrm{O}_{3}$ for this purpose, a material of proven performance thanks to its excellent chemical and physical passivation ${ }^{23-25)}$. After depositing $35 \mathrm{~nm}$ of $\mathrm{Al}_{2} \mathrm{O}_{3}$ on top of our b-Si (thickness determined by ellipsometry and confirmed by TEM images, see next Subsection), we observed a further decrease in reflectance, such that $R$ is lower than $1 \%$ throughout the visible spectrum, which brings the reflectance of our surfaces back on par with that of the structures described in Refs. 5, 17.

The reflectance of the bus-bars is also dramatically reduced by the blackening treatment. The standard bus-bars show reflectance values ranging from $30 \%$ at $300 \mathrm{~nm}$ to above $60 \%$ around $800 \mathrm{~nm}$. After the blackening treatment, $R$ is reduced to just $3.5 \%$ or less throughout the visible spectral range, matching very well the reflectance of our b-Si. 


\subsection{Morphology and lifetime of passivated b-Si.}

Figure 3(a)-(b) show top-view and cross-section SEM images of a wafer textured by our RIE process, respectively. The nanostructures appear as randomly distributed hillocks, with shape generally varying between that of a cone and that of a paraboloid ${ }^{14)}$. The base of the nanostructures has a characteristic dimension between 200 and $300 \mathrm{~nm}$, and a maximum height of about $500 \mathrm{~nm}$. The $\mathrm{Al}_{2} \mathrm{O}_{3}$ coating shows excellent degree of conformity, as expected from $\mathrm{ALD}^{26)}$. The uniformity of the RIE processing can be appreciated from Fig. 3(c), which contains a photograph of a $100 \mathrm{~mm}$ diameter wafer after RIE. Figure 3(d) summarizes effective lifetime measurements on our b-Si and polished reference sample. The effective lifetime of $\mathrm{b}$-Si before passivation is rather low and at most of $10 \mu \mathrm{s}$, as common for non-passivated $\mathrm{Si}$ surfaces ${ }^{27)}$. The lifetime is improved by deposition of $\mathrm{Al}_{2} \mathrm{O}_{3}$, and reaches about $50 \mu \mathrm{s}$. A further improvement of a factor of more than 20 is observed upon annealing of $\mathrm{Al}_{2} \mathrm{O}_{3}$ in $\mathrm{N}_{2}$ ambient at $400{ }^{\circ} \mathrm{C}$ for 10 minutes. The need for annealing (usually at temperatures between $350{ }^{\circ} \mathrm{C}$ and $500{ }^{\circ} \mathrm{C}$, in $\mathrm{N}_{2}$ or forming gas) to activate the passivation effect of $\mathrm{Al}_{2} \mathrm{O}_{3}$ is well-known in the literature ${ }^{27)}$. In our b-Si case, the highest measured effective lifetime is $1.17 \mathrm{~ms}$, not far from the highest lifetime obtained on the passivated, polished Si reference sample $(1.54 \mathrm{~ms})$. This proves that our RIE process is rather gentle and does not damage the Si surface critically.

TEM characterization of nanostructures obtained using different RIE parameters can help elucidating the promising results in terms of effective lifetime. Figure 4(a)-(b) show low magnification TEM images of single nanostructures fabricated using a high RIE platen power $(60 \mathrm{~W})$ and a low RIE platen power $(10 \mathrm{~W})$, respectively. It is clear that the $\mathrm{Al}_{2} \mathrm{O}_{3}$ coating is conformal in both cases. High resolution TEM (HRTEM) imaging, however, reveals a clear difference in the quality of the $\mathrm{Si} / \mathrm{Al}_{2} \mathrm{O}_{3}$ interface. This is crucial for surface recombination ${ }^{25)}$, since a low quality interface may worsen both the chemical passivation (i.e., how dangling bonds in Si are satisfied) and the physical passivation (since it is due to the sheet charge in close proximity of the interface). In the case of high RIE platen power (Fig. 4(c)), we can identify a region of a few $\mathrm{nm}$ in thickness, in which the Si appears to have become amorphous. This is most likely a result of the higher energy and more intense ion bombardment during RIE caused by the higher platen power. On the other hand, in the case of low RIE platen power (Fig. 4(d)) the lattice planes of Si with a distance of $3.13 \AA$ are readily identified, corresponding to the (111) set of planes. These atomic columns of Si extend all the way to the boundary with $\mathrm{Al}_{2} \mathrm{O}_{3}$ without visible damage, which indicates an 
interface of high quality where the $\mathrm{Al}_{2} \mathrm{O}_{3}$ passivation properties are fully exploited.

\subsection{Black bus-bars.}

The surface of blackened bus-bar is shown in the SEM image of Fig. 5(a). Some holes in the coating are visible with characteristic dimensions of around $1 \mu \mathrm{m}$, which however do not affect the functionality and the antireflective properties of the coating. In fact, the coating reduces reflectance dramatically as compared to conventional bus-bars with soldering coating, as already discussed in Section 3.1. Figure 5(b)-(c) show cross-sections of bus-bars before and after stringing, respectively. The soldering coating on the top side does not change during soldering, while some solder material on the back $\mathrm{Si}$ is redistributed due to surface tension. Chemical analysis by energy dispersive X-rays spectroscopy (data not shown here) shows that the coating on the top side has not been damaged by the soldering process or the flux that was used before soldering. The small hole in the top layer on Fig. 5(c) (indicated by the white circle) was caused by one of the pins from the stringer-machine during soldering. However, such hole is not visible from a distance of $1 \mathrm{~m}$. In addition, one can notice a few small imperfections between cell and bus-bar. However, these imperfections in the soldering are not caused by the blackening of the bus-bars, as confirmed by analysis of several crosssections after using the same stringing machine, including standard, non-blackened bus-bars, which all contained similar minute imperfections.

\section{Conclusions}

In this paper, we have introduced black silicon textured by maskless, non-cryogenic reactive ion etch together with black bus-bars towards aesthetically appealing screen-printed, front contacted solar panels. Black silicon coated with $\mathrm{Al}_{2} \mathrm{O}_{3}$ results in a uniform dark appearance with average reflectivity lower than $1 \%$ in the UV-vis part of the solar spectrum, while retaining good minority carrier effective lifetime (up to $1.14 \mathrm{~ms}$ as compared to $1.54 \mathrm{~ms}$ for planar, polished reference wafers). The relatively high effective lifetime of black silicon samples is ascribed to a lower surface and sub-surface damage in the silicon thanks to the lower ion energy during the etching process, as revealed by high resolution transmission electron microscopy analysis. Blackened bus-bars using inorganic treatment combining electroplating and chemical etching results in reflectance lower than $4 \%$ across the UV-vis range, matching the antireflective properties of the black silicon rather well. Current efforts are being devoted to incorporating both black-Si and black bus-bars in a pilot production line of front-contacted panels, while future work will focus on up-scaling the blackening 
process for the bus-bars to an automated line fabricating selective blackening at high speeds. In addition, we have planned accelerated ageing tests on mini-modules in order to assess the reliability and performance over time of our all-black panels.

\section{Acknowledgments}

This project is supported by funding from the EUDP (project number 64016-0030).

\section{References}

(1) S. S. Chicago, S. Hogan, Photovoltaics Bull., 9, 7-9 (2003).

(2) P. B. Rand, J. Genoe, P. Heremans, J. Poortmans, Prog. Photovolt Res. Appl., 15, 659676 (2007).

(3) C. Peng, Y. Huang, Z. Wu, Energy Build., 12, 3592-3598 (2011).

(4) X. Liu, P. R. Coxon, M. Peters, B. Hoex, J. M. Cole, D. J. Fray, Energy Environ. Sci., 7, 3223-3263 (2014).

(5) K. Füchsel, M. Kroll, M. Otto, M. Steglich, A. Bingel, T. Käsebier, R. B. Wehrspohn, E. B. Kley, T. Pertsch, A. Tünnermann, Proc. of SPIE, 8438, 117-151 (2012).

(6) H. Jansen, M. De Boer, R. Legtenberg, M. Elwenspoek, J. Micromechanics Microengineering, 2, 115-120 (1995).

(7) J. S., Yoo, L. O. Parm, U. Gangopadhyay, K. Kim, S. K. Dhungel, D. Mangalaraj, J. Yi, Sol. Energy Mater. Sol. Cells, 90, 3085-3093 (2006).

(8) B. Kafle, T. Freund, A. Mannan, L. Clochard, E. Duffy, S. Werner, P. Saint-Cast, M. Hofmann, J. Rentsch, R. Preu, Energy Procedia, 92, 359-368 (2016).

(9) R. S. Davidsen et. al., Sol. Energy Mater. Sol. Cells, 144, 740-747 (2016).

(10) B. Kafle, A. Mannan, T. Freund, L. Clochard, E. Duffy, M. Hofmann, J. Rentsch, R. Preu, Phys. Status Solidi - Rapid Res. Lett., 9, 448-452 (2015).

(11) J. Oh, H. C. Yuan, H. M. Branz, Nat. Nanotechnol. 7, 743-748 (2012).

(12) X. Li, Y. Xiao, C. Yan, K. Zhou, S. L. Schweizer, A. Sprafke, J.-H. Lee, R. B. Wehrspohn, ECS Solid State Lett., 2, 22-24 (2012).

(13) M. Algasinger, J. Paye, F. Werner, J. Schmidt, M. S. Brandt, M. Stutzmann, S. Koynov, Adv. Energy Mater., 3, 1068-1074 (2013).

(14) M. M. Plakhotnyuk, M Gaudig, R. S. Davidsen, J. M. Lindhard, J. Hirsch, D. Lausch, M. S. Schmidt, E. Stamate, O. Hansen, J. Appl. Phys., 122, 143101 (2017).

(15) H. Savin, P. Repo, G. Von Gastrow, P. Ortega, E. Calle, M. Garín, R. Alcubilla, Nat. Nanotechnol., 10, 624-628 (2015). 
(16) F. Schindler, B. Michl, P. Krenckel, S. Riepe, J. Benick, R. Müller, A. Richter, S. W. Glunz, M. C. Schubert, Energy Procedia, 124, 777-780 (2017).

(17) R. S. Davidsen, J. Ormstrup, M. L. Ommen, P. E. Larsen, M. S. Schmidt, A. Boisen, Ø Nordseth, O. Hansen, Sol. Energy Mater. Sol. Cells, 140, 134-140 (2015).

(18) Solar Ribbon for Photovoltaic Modules, http://www.brukerspaleck.com/en/products/solarband-fuer-photovoltaikmodule-en.

(19) Sachs, E. M. Light Capture with Patterned Solar Cell Bus Wires, US patent (2007).

(20) Light Capturing Ribbon, https://www.pvribbon.com/.

(21) S. W. Park, J. Kim, S. Lee, Application of Acid Texturing to Multi-Crystalline Silicon Wafers. J. Korean Phys. Soc., 43, 423-426 (2003).

(22) K. Kim, S. K. Dhungel, S. Jung, D. Mangalaraj, J. Yi, J. Sol. Energy Mater. Sol. Cells, 92, 960-968 (2008).

(23) B. Hoex, J. J. H. Gielis, M. C. M. Van De Sanden, W. M. M. Kessels, J. Appl. Phys., 104, 113703 (2008).

(24) B. Hoex, M. C. M. van de Sanden, J. Schmidt, R. Brendel, W. M. M. Kessels, Phys. Status Solidi - Rapid Res. Lett., 6, 4-6 (2012).

(25) G. Dingemans, W. M. M. Kessels, J. Vac. Sci. Technol. A Vacuum, Surfaces, Film, 30, 40802, (2012).

(26) S. M. George, Chem. Rev., 110, 111-131 (2010).

(27) A. Cuevas, D. Macdonald, Sol. Energy, 76, 255-262 (2004). 


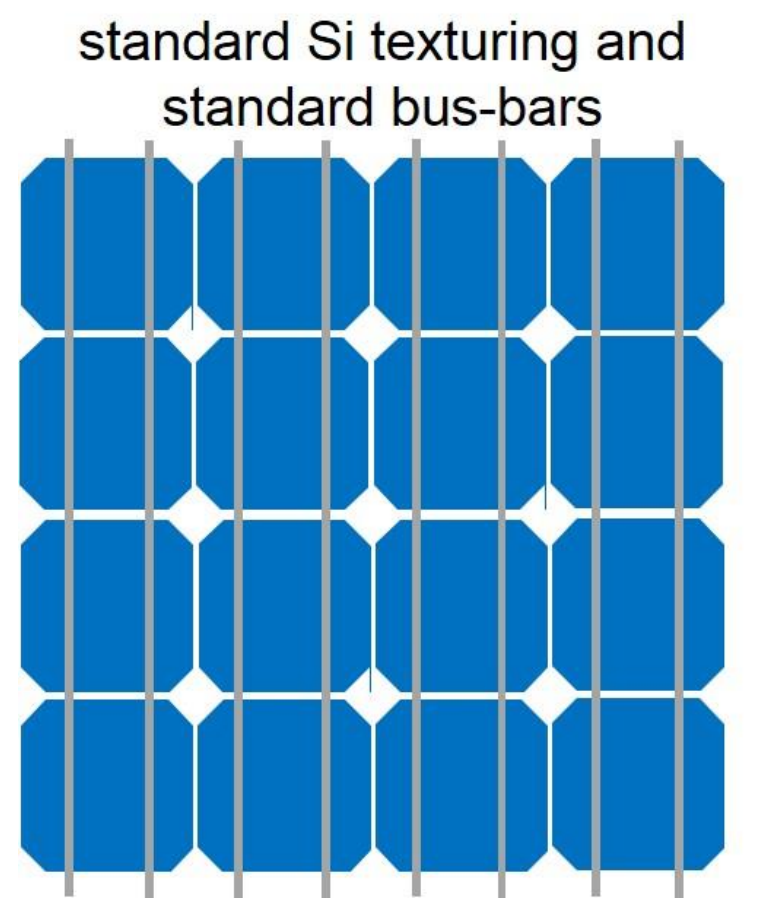

\section{black Si and black bus-bars}

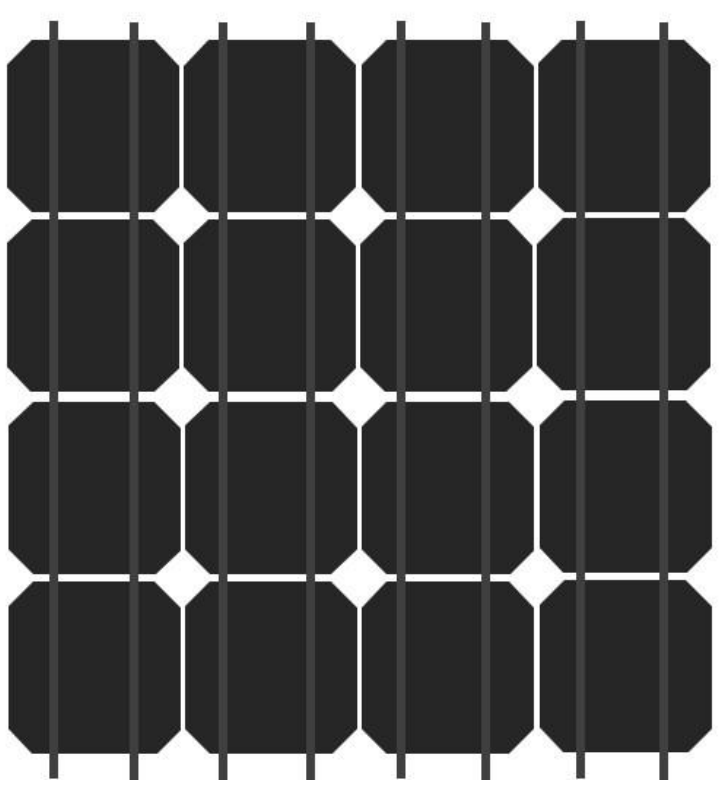

Fig. 1. (Color online). Schematic of front contacted standard cells compared to cells with black silicon and black bus-bars. 

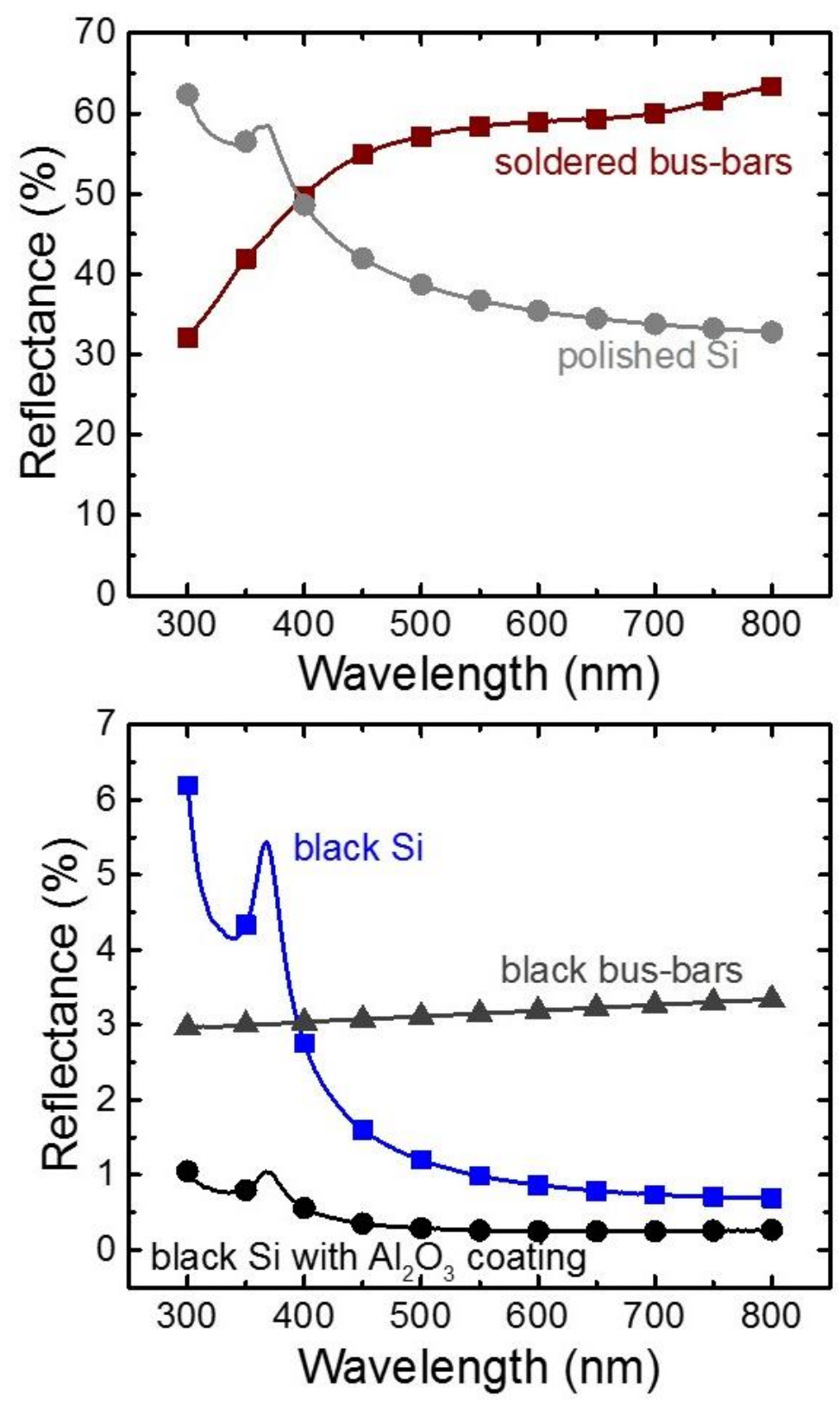

Fig. 2. (Color online). Top: reflectance as function of photon wavelength for $\mathrm{CZ}$, p-type polished $\mathrm{Si}$ (circles) and for standard bus-bars (squares). Bottom: reflectance as function of photon wavelength for b-Si after RIE (squares) and after deposition of $\mathrm{ALD} \mathrm{Al}_{2} \mathrm{O}_{3}$ (circles), as well as for and blackened bus-bars (triangles). 

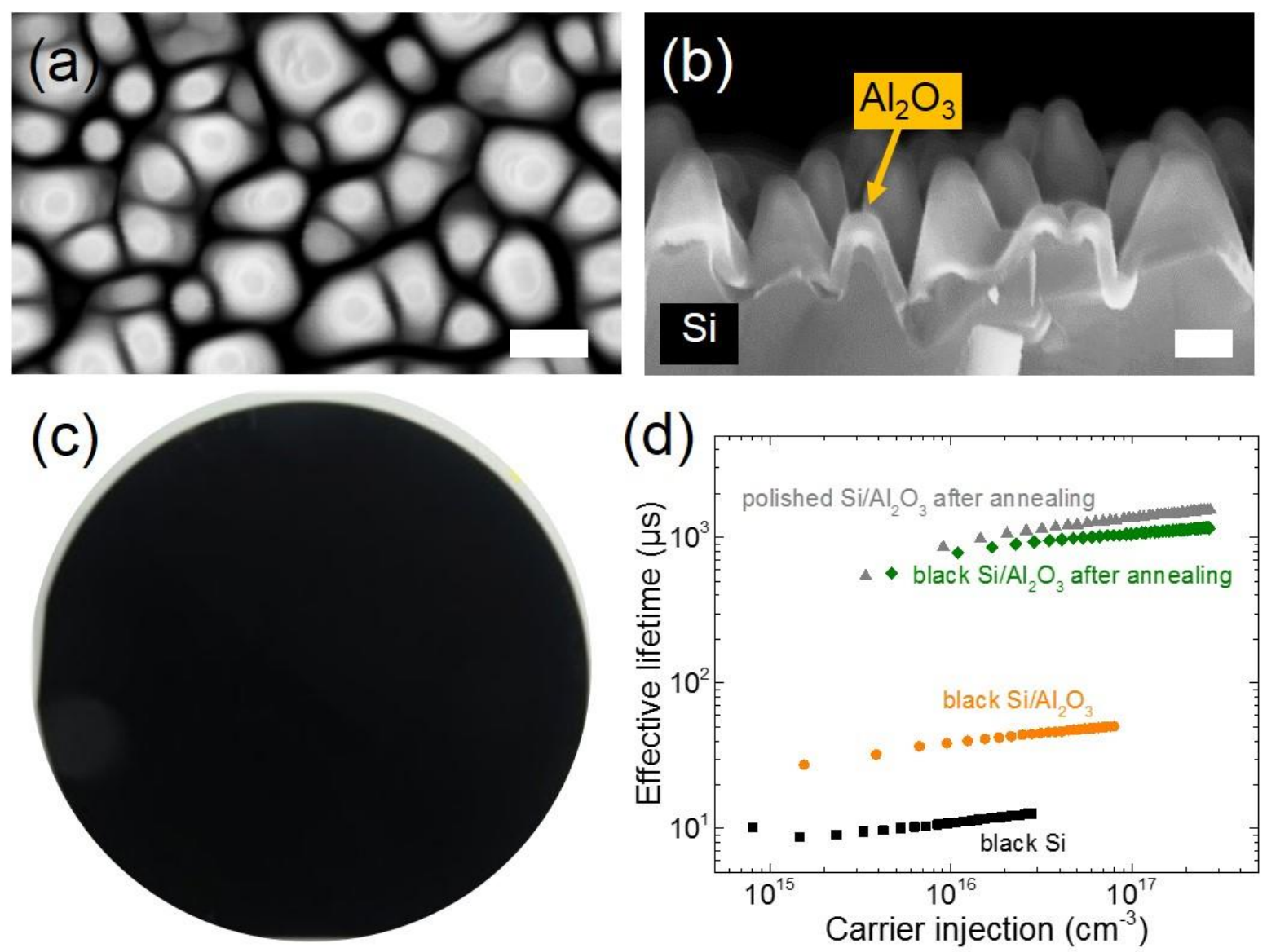

Fig. 3. (Color online). (a) Top-view SEM image of b-Si passivated with ALD $\mathrm{Al}_{2} \mathrm{O}_{3}$. Scale bar is $200 \mathrm{~nm}$. (b) Cross-section SEM image of b-Si passivated with ALD $\mathrm{Al}_{2} \mathrm{O}_{3}$. Scale bar is $100 \mathrm{~nm}$. (c) Photograph of a 4" p-type CZ wafer after texturing with RIE, showing excellent uniformity in the etching process. (d) Effective lifetime measurements on $\mathrm{b}$-Si before passivation (squares), after passivation (circles), and after annealing (diamonds). The effective lifetime of a polished CZ p-type wafer after passivation and annealing is also shown for reference. 

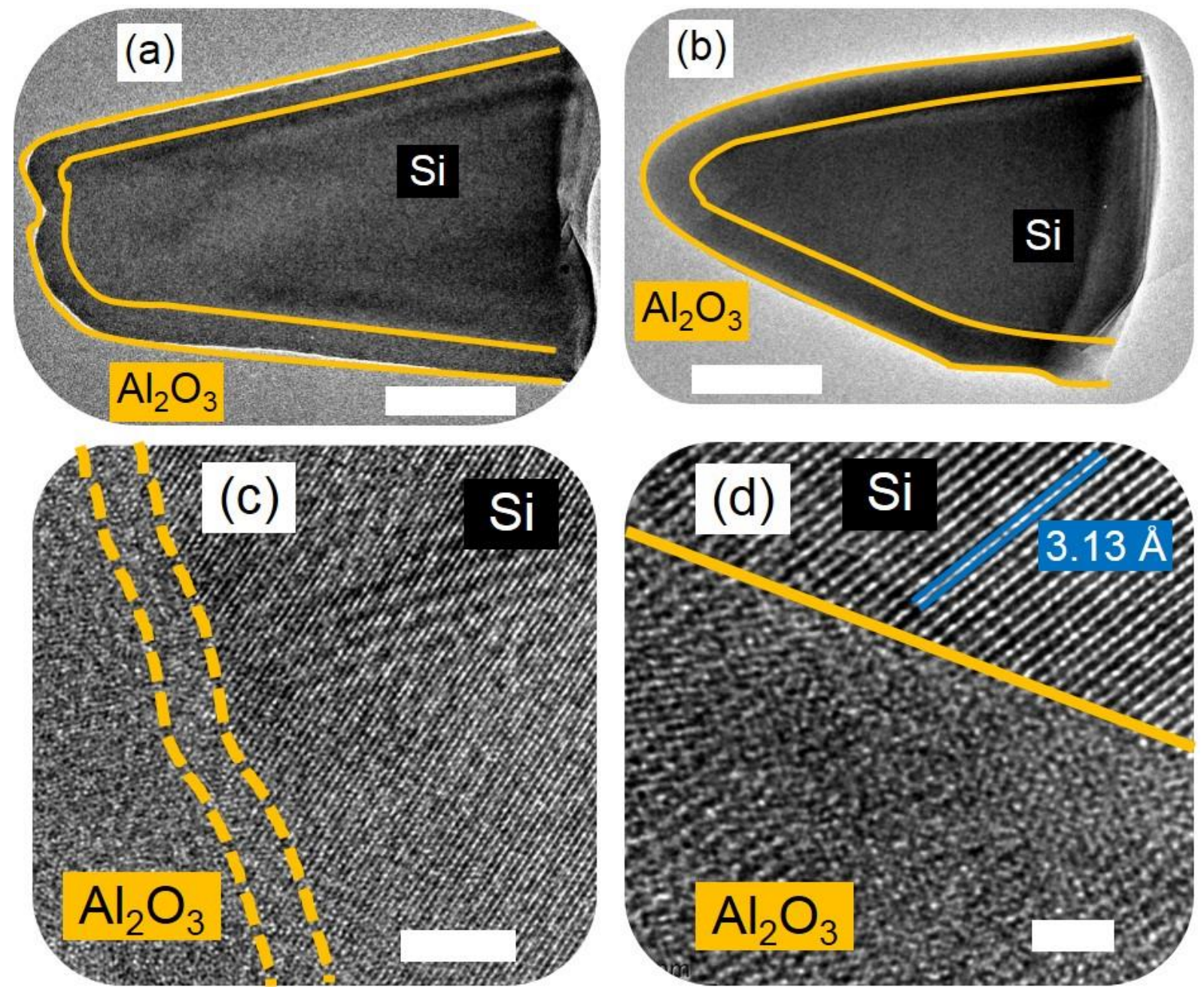

Fig. 4. (Color online). TEM characterization of nanostructures from b-Si. (a) TEM image of a single nanostructure resulting from high surface damage RIE processing. The yellow contours indicate the $\mathrm{Al}_{2} \mathrm{O}_{3}$ passivation layer deposited by ALD. The scale bar is $100 \mathrm{~nm}$. (b) TEM image of a single nanostructure resulting from low surface damage RIE processing (i.e. same wafers used for lifetime measurements shown in Fig. 3(d)). The yellow contours indicate the $\mathrm{Al}_{2} \mathrm{O}_{3}$ passivation layer deposited by ALD. The scale bar is $100 \mathrm{~nm}$. (c) HRTEM image of the $\mathrm{Si} / \mathrm{Al}_{2} \mathrm{O}_{3}$ interface in the nanostructure shown in (a). The interface is not clear and a region of disorder (with possibly amorphized $\mathrm{Si}$ ) is visible. Scale bar is $5 \mathrm{~nm}$. (d) HRTEM image of the $\mathrm{Si} / \mathrm{Al}_{2} \mathrm{O}_{3}$ interface in the nanostructure shown in (b). A much clearer interface is visible. The atomic columns of Si extend all the way to the interface (the distance between planes is $3.13 \AA$, corresponding to the (111) set of planes. Scale bar is $2 \mathrm{~nm}$ 

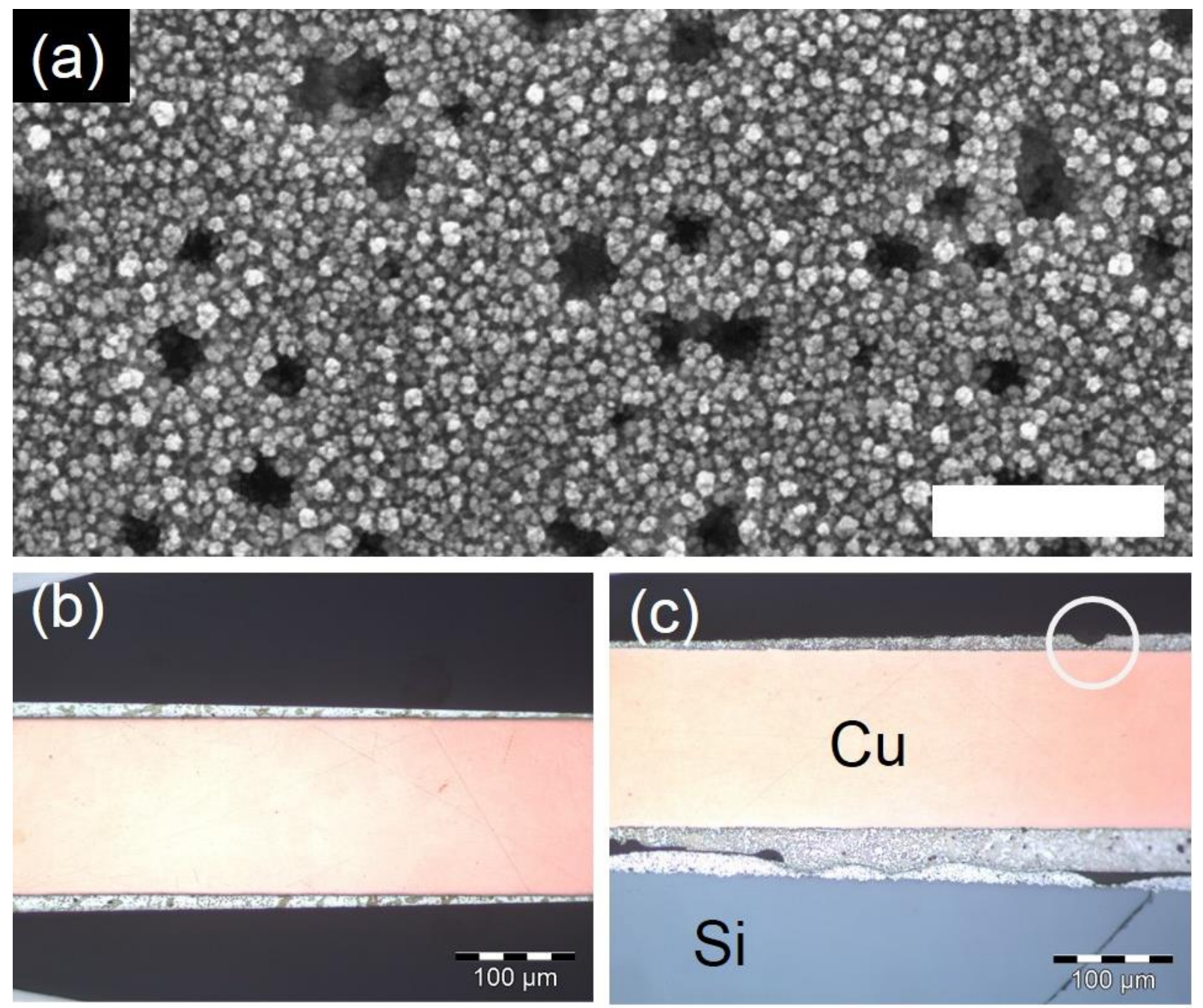

Fig. 5. (Color online). (a). Top-view SEM image of surface of blackened bus-bar. Scale bar is $5 \mu \mathrm{m}$. (b) Optical microscope of a polished cross-section of blackened bus-bars before stringing. (c) Optical microscope of a polished cross-section of blackened bus-bars after stringing. The white circle indicates a small hole caused by a pin during the stringing process, which however is not visible from a distance of $1 \mathrm{~m}$. 